\title{
Tinjauan Yuridis Normatif Atas Perlindungan Hukum Bagi Pasien Sebagai Konsumen Dalam Malpraktek Di Rumah Sakit
}

\author{
Fauji Salim \\ Fakultas Hukum Universitas Islam Indonesia Yogyakarta Indonesia \\ Jln. Cik Di Tiro No. 1, Yogyakarta, Indonesia 55223 \\ faujisalim@gmail.com
}

\begin{abstract}
Medical malpractice occurs when doctors make mistakes in fulfilling their obligations, namely providing medical services to patients, which causes civilian losses. This is often accompanied by consequences that become the elements of certain criminal acts. Therefore, this study aims to answer two problems: First, what is the normative juridical review of consumer protection for patients in hospitals? Second, how is consumer protection for patients in the event of malpractice in the hospital? This is a normative juridical research with a statutory approach, this study concludes that the purpose of running a hospital according to the Hospital Law is to provide legal certainty to patients, society and human resources, so the hospital plays an important role in monitoring every doctor's activity in carrying out his profession. so that there is no negligence that could harm the patient and the doctor himself; Meanwhile, legal protection and health services include administrative, civil and criminal aspects.
\end{abstract}

Key Words: Hospital; legal protection; medical consumet

\begin{abstract}
Abstrak
Malpraktik kedokteran terjadi apabila dokter melakukan kesalahan dalam memenuhi prestasinya yakni memberikan pelayanan medis kepada pasien sehingga menimbulkan kerugian secara keperdataan. Hal ini tak jarang dibarengi dengan akibat yang menjadi unsur tindak pidana tertentu. Maka dari itu penelitian ini bertujuan untuk menjawab dua permasalahan: Pertama, bagaimana tinjauan yuridis normatif atas perlindungan konsumen bagi pasien di rumah sakit? Kedua, bagaimana perlindungan konsumen bagi pasien dalam hal terjadinya malpraktek di rumah sakit? Penelitian ini bersifat yuridis normatif dengan pendekatan undang-undang, penelitian ini menyimpulkan bahwa tujuan penyelenggaraan rumah sakit menurut UU Rumah Sakit adalah memberikan kepastian hukum kepada pasien, masyarakat dan sumber daya manusia, maka rumah sakit berperan penting untuk memantau setiap aktifitas dokter dalam hal menjalankan profesinya agar tidak terjadi kelalaian yang merugikan pasien dan dokter itu sendiri; sedangkan perlindungan hukum dan pelayanan kesehatan meliputi ada aspek administrasi, aspek perdata dan aspek pidana.
\end{abstract}

Kata-kata Kunci: Konsumen medis; perlindungan hukum; rumah sakit 


\section{Pendahuluan}

Tindakan kedokteran dalam memberikan pelayanan kesehatan juga harus berhati-hati karena akan mengakibatkan terjadinya pelanggaran tindakan medis dan harus memenuhi persyaratan guna memberikan pelayanan medis terhadap pasien di rumah sakit. Adapula dokter yang melakukan praktik di luar rumah sakit guna mencari penghasilan tambahan yang bukan hanya didapat di rumah sakit saja, melainkan juga diluar rumah sakit untuk memenuhi kebutuhannya.

Rumah Sakit merupakan tempat rujukan kesehatan bagi banyak orang yang ingin berobat, atau sekedar memeriksa kesehatannya, tentu saja keberadaan rumah sakit merupakan suatu kebutuhan yang sangat primer, karena sifat kebutuhannya sangat vital maka dengan adanya Rumah Sakit dengan kelengkapan fasilitasnya seharusnya menjadi kebanggaan tersendiri bagi masyarakat yang tinggal disekitarnya. ${ }^{1}$ Akan tetapi kebanyakan masyarakat yang tidak mampu tidak bisa menikmati fasilitas rumah sakit yang serba komplet karena dengan biaya yang cukup mahal sehingga bagi masyarakat tidak mampu (miskin) tidak bisa berobat di rumah sakit tertentu, bahkan dengan adanya program pemerintah yang saat ini masih berjalan yaitu BPJS pun masih tidak beroperasi dengan baik misalnya pelayanan di rumah sakit, pasien BPJS tidak akan di layani dengan cepat karena proses administrasinya lambat dari pihak pemerintah sehingga rumah sakit tertentupun enggan melayani pasien tertentu karena masih kendala administrasi, bahkan ada beberapa rumah sakit yang menolak bekerja sama dengan BPJS walaupun bpjs merupakan subsidi silang.

Jika terjadinya sebuah pelanggaran di rumah sakit yang dilakukan oleh dokter/dokter gigi maupun tenaga kesehatan lainnya yang berkerja di rumah sakit maka Rumah Sakit tersebut bisa dimintai pertanggungjawaban atas perbuatan tenaga kesehatan yang mengakibatkan kerugian materil terhadap pasien.

Telah tertuang dalam Undang-Undang RI Nomor 44 Tahun 2009 tentang Rumah Sakit Pasal 45 ayat (1) menyatakan, "Rumah Sakit tidak dapat dituntut dalam melaksanakan tugas dalam rangka penyelamatan nyawa manusia." Selanjutnya Undang-Undang RI Nomor 44 Tahun 2009 tentang Rumah Sakit Pasal 46 juga menyatakan, ${ }^{2}$ "Rumah Sakit bertanggung jawab secara hukum terhadap semua kerugian yang ditimbulkan atas kelalaian yang dilakukan oleh tenaga kesehatan di Rumah Sakit."

${ }^{1}$ Maskawati dkk, Hukum Kesehatan, Cetakan Kesatu, Litera, Yogyakarta, 2018, hlm. 77.

2 Undang-Undang No. 44 Tahun 2009 tentang Rumah Sakit. 
Oleh sebab itu perbuatan dokter/dokter gigi tidak terlepas daripada tanggung jawab rumah sakit, kecuali dokter yang bersangkutan melakukan pelanggaran pada saat sedang berpraktik diluar rumah sakit.

Menurut penulis Pelayanan kesehatan yang diberikan seorang dokter kepada pasien merupakan tindakan profesi kedokteran. Tindakan kedokteran merupakan suatu tindakan yang penuh dengan risiko. Risiko tersebut dapat terjadi disebabkan oleh sesuatu yang tidak dapat di prediksi sebelumnya atau risiko yang terjadi akibat tindakan dokter yang salah. Diartikan tindakan salah apabila dokter tidak melakukan pekerjaannya sesuai dengan standar profesi medik \& prosedur tindakan medik. Apabila seorang dokter melakukan tindakan salah, maka dokter tersebut dapat dikategorikan melakukan tindakan malpraktik, sehingga dapat menyangkut aspek hukum pidana. Oleh sebab itu hak-hak pasien sanggat penting untuk dilindungi, dokter tidak boleh seenaknya mengambil tindakan medis apabila dokter tersebut tidak memiliki keahlian khusus di bidang tertentu dan juga harus sesuai dengan SOP (Standard Operational).

Oleh sebab itu dokter dan rumah sakit yang bersangkutan harus bertanggung jawab atas perbuatan yang telah dilakukan berdasarkan UndangUndang No. 22 Tahun 1999, karena pemerintah tidak lagi memberikan subsidi atau anggaran yang dibutuhkan rumah sakit karena dengan adanya otonomi tersebut, Maka dari itu dokter dan/atau rumah sakit harus mempertanggung jawabkan atas kerugian yang dialami pasien sebagai konsumen jika terjadinya kesalahan yang di lakukan dokter di rumah sakit.

Banyak kasus malpraktek yang terjadi di rumah sakit yang di posting di media massa atau media elektronik lainnya, salah satunya adalah:

kasus Selvy korban malpraktek RS Graha Kedoya pada tgl 21/04/2015. Bahwa pasien di vonis terindikasi kista, pasien di rekomendasikan untuk menemui dokter kandungan, HS nama dokter yang melakukan operasi kista, akan tetapi operasi yang dilakukan dokter HS juga mengangkat dua indung telur yang tanpa seijin pasien. Sedang dalam UU kesehatan, dokter tidak punya hak untuk melakukan operasi pengangkatan tanpa seijin pasien, kecuali dalam keadaan darurat atau kedaruratan medis. ${ }^{3}$

Ada juga kasus malpraktek yang terjadi pada 29/04/2010 di Rumah Sakit Umum Krian Husada:

Terdakwa yang bernama dr. Wida Pratama Astiti, meminta perawat Setyo Mujiono untuk melakukan penyuntikan KCL 12,5 ml kepada pasien Dava Chahyanata Oktaviana tanpa pengawasan terdakwa dr. Wida, karena terdakwa masih berada di

3 "Fakta Kasus Dugaan Malpraktek Rumah Sakit Grha Kedoya Kronologi Hingga Pernyataan Pihak Rumah Sakit", http://wow.tribunnews.com/2018/07/11/9-fakta-kasus-dugaan-malpraktik-rs-grha-kedoyakronologi-hingga-pernyataan-pihak-rumah-sakit, diakses tanggal 14 Desember 2017. 
poli umum, sehingga menyebabkan pasien Dava mengalami kejang-kejang. Berdasarkan keterangan ahli, seharusnya penyuntikan KCL dapat dilakukan dengan cara mencampurkan ke dalam infuse sehingga cairan KCL dapat masuk ke dalam tubuh penderita dengan cara masuk secara pelan-pelan. Akibat dari kelalaian terdakwa mengakibatkan pasien Dava meninggsl dunia. Putusan No.590 K/Pid/2012

Pasien sebagai konsumen, pasien harus di perlakukan dengan baik tidak boleh seenaknya melakukan tindakan sebelum di ijinkan oleh pasien karena akan merugian pasien dan dokter yang menangani pasien itu sendiri, tindakan itu bisa dilakukan tanpa ijin pasien jika keadaan pasien tersebut dalam keadaan kedaruratan medis dan harus di ambil tindakan cepat untuk menyelamatkan nyawa pasien atau konsumen rumah sakit.

Dari latar belakang masalah tersebut diatas maka penulis sangat tertarik untuk mengkaji serangkaian kasus, khususnya tindak pidana malpraktek medic, dalam penelitian ini penulis mengangkat judul: Tinjauan Yuridis Normatif atas Perlindungan Konsumen bagi Pasien sebagai Konsumen dalam Malpraktek di Rumah Sakit.

\section{Rumusan Masalah}

Berdasarkan uraian di atas, adapun rumusan masalah yang dipaparkan dalam penelitian ini: Pertama, bagaimana tinjauan yuridis normatif atas perlindungan konsumen bagi pasien di rumah sakit? Kedua, bagaimana perlindungan konsumen bagi pasien dalam hal terjadinya malpraktek di rumah sakit?

\section{Tujuan Penelitian}

Adapun tujuan penelitian ini sebagai berikut: Pertama, untuk mengetahui bagaimana tinjauan yuridis normatif atas perlindungan konsumen bagi pasien di rumah sakit. Kedua, untuk mengetahui bagaimana perlindungan konsumen bagi pasien dalam hal terjadinya malpraktek di rumah sakit.

\section{Metode Penelitian}

\section{Jenis Penelitian}

Penelitian tesis ini merupakan penelitian yuridis normatif yakni menggunakan metode pendekatan undang-undang yang di lakukan dengan 
menelaah undang-undang dan regulasi yang bersangkut paut dengan masalah hukum yang sedang di teliti. ${ }^{4}$

\section{Objek Penelitian}

Objek penelitian berdasarkan judul tesis ini “Tinjauan Yuridis Normatif atas Perlindungan Konsumen bagi Pasien Dalam Hal Terjadinya Malpraktek Di Rumah Sakit" adalah a. Tinjauan yuridis normatif atas perlindungan konsumen bagi pasien di rumah sakt; b. Perlindungan konsumen bagi pasien dalam hal terjadinya malpraktek di rumah sakit;

\section{Teknik Pengumpulan Data}

Pengumpulan data dilakukan dengan studi kepustakaan. Studi kepustakaan yaitu penelitian yang dilakukan dengan menggunakan literatur (kepustakaan) ${ }^{5}$. Baik berupa buku-buku, jurnal ilmiah, media internet, serta reverensi lain yang relevan guna menjawab rumusan dalam permasalahan ini.

\section{Analisis Data}

Untuk menganalisis bahan hukum yang telah terkumpul di dalam penelitian ini, analisis dilakukan saecara deskriptif kualitatif. Deskriptif artinya memberikan data yang sedetail mungkin agar dapat membantu di dalam memperkuat teoriteori lama, atau dalam rangka menyusun teori baru. ${ }^{6}$ Kualitatif maksudnya adalah suatu cara menganalisis yang menghasilkan data deskriptif-analisis, yaitu apa yang didapat dari bahan-bahan hukum yang telah di pelajari. Bahan hukum/data yang bersifat deskriptif, maka analisisnya kualitatif yang menekankan pada penalaran. ${ }^{7}$

\section{Hasil Penelitian dan Pembahasan}

Tinjauan Yuridis Normatif atas Perlindungan Konsumen bagi Pasien di Rumah Sakit

Perlindungan hukum adalah memberikan pengayoman kepada hak asasi manusia (HAM) yang di rugikan orang lain dan perlindungan tersebut diberikan kepada masyarakat agar mereka dapat menikmati semua hak-hak yang diberikan oleh hukum atau dengan kata lain perlindungan hukum adalah berbagai upaya hukum yang harus diberikan oleh aparat penegak hukum untuk memberikan

\footnotetext{
${ }^{4}$ M. Syamsudin, Operasional Penelitian Hukum, PT Raja Grafindo Persada, Jakarta, 2007, hlm. 58

${ }^{5}$ Iqbal Hasan, Pokok-Pokok Materi Metodologi Penelitian dan Aplikasinya, Ghalia Indonesia, Jakarta, 2002,

${ }^{6}$ Soerjono Soekanto, Pengantar Penelitian Hukum, UI Press, Jakarta, 1986, hlm. 10

${ }^{7}$ Universitas Islam Indonesia, Buku Pedoman Penulisan Tugas Akhir (tesis) Program Magister Ilmu Hukum, FH
} hlm. 11 UII Press, Yogyakarta, 2010, hlm. 14. 
rasa aman, baik secara pikiran maupun fisik dari gangguan dan berbagai ancaman dari pihak manapun. ${ }^{8}$

Perlindungan hukum ini bukan hanya semata-mata melindungi hak pasien akan tetapi juga melindungi dokter dalam menjalankan profesinya apakah dokter melakukan tindakan sudah sesuai dengan SOP ataukah tidak. Maksudnya apakah dokter menjalankan tugasnya sudah sesuai dengan profesinya atau tidak, jika tidak maka dokter tersebut masuk dalam kategori malpraktek.

Perlindungan hukum adalah tindakan atau upaya untuk melindungi masyarakat dari perbuatan sewenang-wenang oleh penguasa yang tidak sesuai dengan aturan hukum untuk mewujudkan ketertiban dan ketentraman sehingga memungkinkan manusia untuk menikmati martabatnya sebagai manusia. ${ }^{9}$

Perlindungan hukum menurut Philipus Hadjon ada dua bentuk: pertama, perlindungan hukum preventif yang artinya rakyat diberikan kesempatan menyatakan pendapatnya sebelum keputusan pemerintah mendapat bentuk yang devenitiv yang bertujuan untuk mencegah terjadinya sengketa. Kedua, perlindungan hukum represif yang bertujuan untuk menyelesaikan sengketa. ${ }^{10}$

Penulis berkesimpulan dari pernyataan Philipus Hadjon yang membagi perlindungan hukum menjadi dua bentuk, poin pertama ini sering terjadi dalam dunia medis tapi tidak selalu membuakan hasil seperti yang di sampaikan oleh Hadjon karna sebagian besar konsumen rumah sakit bukan hanya di rugikan secara materil melaikan juga imateril jadi harus di tempuh jalur hukum karena setiap konsumen juga memiliki hak-hak yang harus di lindungi begitupun sebaliknya, di dunia kedokteran yang menentukan salah dan/atau tidaknya adalah MKDKI karena yang mengerti dan paham tindakan dokter tersebut salah atau tidak adalah MKDKI setelah itu baru di limpahkan ke penyelidikan.

Menurut dr Nasir dalam perkuliahan beliau pernah menyampaikan jika terjadinya tindakan salah yang di lakukan oleh dokter, maka yang menentukan salah dan tidaknya adalah MKDKI karena mereka lebih memamahi tidakan kedokteran jadi tidak serta merta langsung di nyatakan tindakan tersebut adalah perbuatan malpraktik.

Penulis juga sepakat dengan hal itu, akan tetapi jika kita kaitkan dengan kasusnya Silvia yang di diaknose berbeda harus di pertanyakan apakah harus di limpahkan ke MKDKI atau tidak, sedangkan faktanya dia hanya mengalami

\footnotetext{
${ }^{8}$ Sajipto Rahardjo, "Penyelenggaraan Keadilan Dalam Masyarakat Yang Sedang Berubah", Jurnal Masalah Hukum, 1993.

9 Setiono, "Rule of Law (Supremacy Hukum)", Tesis, Magister Ilmu Hukum Program Pascasarjana Universitas Sebelas Maret, Surakarta, 2014, hlm. 3.

${ }^{10} \mathrm{Ibid}$, hlm. 4.
} 
penyakit kista di keramdisnya yang pertama tetapi yang yang terjadi mala sel telurnya yang diangkat, rekamedisnya yang pertama tidak dikasih, yang mereka tunjukan/memberikan kopiannya adalah rekamedis kedua, dan itu jelas terbukti salah.

Undang-Undang Nomor 10 Tahun 1961 tentang Barang, dalam pertimbangannya menyebutkan "kesehatan dan keselamatan rakyat, mutu dan susunan (komposisi) barang". Penjelasan undang-undang ini menyebutkan variasi barang dagangan yang bermutu kurang baik atau tidak baik dapat membahayakan dan merugikan kesehatan rakyat.

UU Nomor 10 Tahun 1961 tentang barang, kata barang memiliki arti yang luas hanya saja setiap orang akan memaknainya berbeda-beda, obat-obatan di rumah sakit juga dikategorikan barang yang di komsumsi setiap orang jika orang tersebut membutuhkannya, misalnya saat orang tersebut dalam keadaan sakit, obat-obatan juga harus memiliki mutuh yang baik agar di konsumsi tidak membahayakan kesehatan konsumen, setiap pasien di rumah sakit sebelum mengkonsumsi obat dia harus di diaknose dulu apakah pasien tersebut alergi dengan obat yang akan di berikan atau tidak, agar tidak membahayakan dan/atau memperburuk keadaan pasien. Pasien yang mengalami gejala saat mengkonsumsi obat biasanya di sebut dalam istila kedokteran Steven jonson sindrom, gejala itu terjadi ketika pasien mengkonsumsi obat yang tidak cocok dengan tubuhnya. Tetati gejala seperti itu akan dikatakan sebagai resiko medis, sedangkan dalam hukum pidana akan dikatakan sebagai kelalaiam karna ada tolak ukurnya, karena setiap dokter yang menangani pasien sebelum memberikan obat dia harus mengdiaknasa terlebih dahulu supaya tidak terjadi gejala yang tidak di inginkan.

Undang-Undang Nomor 23 Tahun 1992 tentang Kesehatan, menggunakan istilah "setiap orang" untuk pemakai, pengguna dan/atau pemanfaatan jasa kesehatan dalam konteks konsumen, hal ini disebutkan dalam Pasal 1 angka 1, Pasal 3, 4, 5 dan Pasal 46. Istilah "masyarakat" juga digunakan dalam undangundang ini dengan asumsi sebagai konsumen, hal ini termaktup dalam Pasal 9, 10 dan Pasal 21.

Undang-Undang Nomor 8 Tahun 1999 tentang Perlindungan Konsumen menyebutkan; Konsumen ${ }^{11}$ adalah setiap orang yang memakai ${ }^{12}$ barang dan/atau

11 Konsumen yang dimaksud dalam Undang-Undang Perlindungan Konsumen adalah setiap yang berstatus sebagai pemakai barang dan/atau jasa, yang berkonotasi pada konsumen akhir. Lihat Penjelasan Pasal 1 Angka 2 Undang-Undang Nomor 8 Tahun 1999 tentang Perlindungan Konsumen

12 Istilah "pemakai" dala hal ini menunjukan bahwa barang dan/atau jasa yang dipakai tidak serta-merta hasil dari transaksi jual beli, melainkan dapat juga diperoleh dari pemberian, hibah/memabntuh/menolong, sewa-menyewa dan lain sebagainya. Lihat dalam KUH Perdata, KUH Dagang. 
jasa ${ }^{13}$ yang tersedia dala masyarakat ${ }^{14}$, baik bagi kepentingan diri sendiri, keluarga, orang lain maupun makhluk hidup lainnya dan tidak untuk di perdagangkan.

Beberapa referensi di atas yang penulis cantumkan, menjelaskan tentang konsumen atau pengguna bukan berarti pasien tidak indektik dengan konsumen, menurut hemat penulis konsumen dan pasien hanya perbedaan di diksinya saja tetapi maknanya sama, konsumen yang diatur dalam KUHPerdata dan KUHDagang dalam peranjian menentukan sedangkan dalam UU Kesehatan tidak menjanjikan hasil melainkan upaya maksimal dari tindakan kedokteran oleh karenanya pasien sebagai konsumen juga membutukan perlindungan yang sama sebagai konsumen rumah sakit.

\section{Perlindungan Pasien dalam Malpraktik di Rumah Sakit}

Di dalam peraturan pelayanan kesehatan untuk masyarakat di Indonesia, secara filosofis berasal dari Pasal 34 ayat (1) UUD 1945 yang menetapkan pelayanan kesehatan sebagai tanggung jawab negara, dan Pasal 28H ayat (1) yang menetapkan mengenai hak warga negara untuk mendapatkan pelayanan kesehatan. Kedua pasal tersebut merupakan perwujudan dari sila kemanusiaan yang adil dan beradap dan sila keadilan sosial bagi seluruh rakyat Indonesia. Penyediaan pelayanan kesehatan berkaitan dengan nilai yang menunjung harkat martabat manusia Indonesia, sedangkan penetapan hak untuk mendapatkan mendapatkan pelayanan kesehatan merupakan perwujudan dari sila keadilan sosial yang diwujudkan oleh pemerataan.

Pemerintah mempunyai tanggung jawab untuk menjamin setiap warga negara memperoleh pelayanan kesehatan yang berkualitas sesuai dengan kebutuhan. Sebagai suatu kebutuhan dasar, setiap individu bertanggung jawab untuk memenuhi kebutuhan hidup dirinya dan orang-orang yang menjadi tanggung jawab, sehingga pada dasarnya pemenuhan kebutuhan masyarakat terhadap kesehatan adalah tanggung jawab setiap warga negara. Setiap warga negara sesuai dengan kodratnya berkewaiban untuk memenuhi kebutuhan dasar

13 Istilah barang dan/atau jasa mengacu kepada terminologi kata "produk", dalam dunia perbankan, istilah produk juga dipakai untuk menamakan jenis-jenis layanan perbankan. Undang-undang perlindungan konsumen pasal 1 angka 4 dan 5 menjelaskan; barang adalah setiap benda baik berwujud maupun tidak, baik bergerak maupun tidak bergerak, dapat di habiskan maupun tidak. Sedangkan jasa adalah setiap layanan berbentuk pekerjaan atau prestasi yang di sediakan bagi masyarakat untuk di manfaatkan oleh konsumen.

14 Barang dan/atau jasa yang di tawarkan kepada masyarakat sudah harus tersedia di pasaran, bahwa pelaku usaha dilarang menawarkan, mempromosikan, mengiklankan suatu barang dan/atau jasa secara tidak benar, dan/atau seolah-olah barang dan/atau jasa tersebut tersedia. Pasal 9 ayat 1 huruf (e) Undang-Undang Nomor 8 Tahun 1999 Tentang Perlindungan Konsumen. 
hidupnya dengan memanfaatkan seluruh potensi manusiawi yang dimilikinya. Sebaliknya, pemerintah pusat dan pemerintah daerah berkewajiban menjamin agar setiap warga negaranya dapat mengunakan haknya untuk memenuhi kebutuhan hidupnya tanpa hambatan atau halangan dari pihak manapun. ${ }^{15}$ Dalam rangka melindungi hak warga negara inilah di perlukan perlindungan hukum dalam pelayanan kesehatan. ${ }^{16}$

Perlindungan hukum dan pelayanan kesehatan meliputi: aspek administrasi; aspek pidana; dan aspek perdata. Pertama, aspek administrasi berkaitan dengan jenis dan mutu pelayanan dasar yang merupakan urusan pemerintah untuk menjamin keselamatan pasien di rumah sakit. SPM menjadi acuan penyelenggaraan layanan rumah sakit, yang pada dasarnya adalah bisnis dibidang layanan kesehatan yang dilakukan ole institusi. Sebagaimana dinyatakan dalam Pasal 1 Undang-Undang Nomor 44 Tahun 2009 bahwa layanan kesehatan rumah sakit dilakukan oleh institusi pelayanan kesehatan yang menyelenggarakan pelayanan kesehatan perorangan secara paripurna yang menyediakan pelayanan rawat inap, rawat jalan, dan gawat darurat. ${ }^{17} \mathrm{Kedua}$, aspek pidana dalam perlindungan warga masyarakat untuk memperoleh layanan kesehatan masyarakat merupakan aspek represif, yaitu ketika teradinya malpraktik oleh dokter ruma sakit. Dalam aspek ini lebih sering menyasar kepada dokter rumah sakit daripada rumah sakitnya. Dalam studi kasus mengenai dr. Dewa Ayu Sasiary, aspek pidana mengedepankan tuntutan terhadap kesalahan dokter, dan rumah sakit tidak bertanggung jawab atas kesalahan itu. Dokter ayu dan kawan-kawannya didakwa dengan Pasal 359 KUHP, bersalah melakukan tindak pidana perbuatan yang karena kealpaannya menyebabkan matinya orang lain.

Kejadian yang menimpa dr. Ayu berlangsung pada April 2010. Kala itu, dr. Ayu bersama rekanya yaitu dr. Hendri Simanjuntak dan dr. Hendi Siagian sedang menangani pasien rujukan Puskesmas di daerah Manado. Karena keadaan terdesak, dr. Ayu melakukan tindakan operasi cito secsio sesaria. Tetapi tindakan itu gagal menyelamatkan pasien. Selang beberapa waktu pasca kejadian, dr. Ayu dan kawan-kawannya mendapat panggilan dari kepolisian. Dia dilaporkan oleh keluarga pasien karena melakukan operasi tanpa ijin.

Pada 2011, persidangan di Pengadilan Negeri (PN) Manado, dr. Ayu di tuntut pidana 10 bulan penjara. Tetapi dr. Ayu divonis bebas karena tidak terbukti melakukan Malpraktik. Jaksa Penuntu Umum (JPU) yang menangani

15 Ibid., hlm. 9

16 Zahir Rusyad, Hukum Perlindungan Pasien, Setara Press, Malang, 2018, hlm. 3.

17 Pasal 1 Undang-Undang No. 44 Tahun 2009 tentang Rumah Sakit. 
kasus itu melakukan kasasi dan dikabulkan MA lewat putusan yang dikeluarkan pada 18 November 2012. Kasasi ini memerintahkan dr. Ayu untuk di penjara selama 10 bulan.

Para dokter di seluruh tanah air turun ke jalan untuk meminta dr. Ayu di bebaskan. Bahkan para dokter melakukan aksi mogok hampir di seluruh provinsi karena berduka atas hukuman yang diberikan kepada dr. Ayu dan kawankawannya. Aksi para dokter ini membuakan hasil. Pada Ferbruari 2014 dr. Ayu dibebaskan lewat putusan di tingkat Peninjauan Kembali (PK) dasar pertimbangan mengabulkan PK yaitu para terpidana tidak menyalahi SOP dalam penanganan operasi seco ciceaseria sehingga pertimbangan judex facti pada PN Manado sudah tepat dan benar. ${ }^{18}$

Kasus ini menjadi perbincangan media, dan berbagai pertanyaan mengemuka mengenai pertanggung jawaban rumah sakit sebagai korporasi yang melakukan transaksi trapeutik. Pada satu sisi, transaksi trapeutik adala hubungan hukum antar rumah sakit dengan pasien yang memberikan kewenangan kepada rumah sakit untuk melakukan kegiatan pelayanan kesehatan kepada pasien.19 Pada sisi lain, tindakan medis dokter searusnya berdasar informend concent, ${ }^{20}$ yang merupakan persetujuan pasien atau keluarganya. Dengan kata lain tindakan hukum yang dilakukan oleh dokter Ruma Sakit adalah karena kewenangan yang diberikan rumah sakit kepada dokter yang bersangkutan, sekalipun kemudian dokterlah yang malakukan tindakan medis kepada pasien di rumah sakit tersebut. Dalam hal ini dokter Ayu tidak meminta persetujuan, karena memandang keadaan pasien sangat darurat. ${ }^{21}$

Ketiga, aspek perdata juga berkaitan dengan perlindungan represif, yaitu perlindungan hukum apabila terjadi kerugian yang disebabkan oleh kesalahhan/kelalaian dokter. Gugatan dilakukan ketika dokter rumah sakit diduga melakukan kelalaian/kesalahan dalam kontra prestasi atas dasar persetujuan rencana tindakan medic informed consent yang memuat di samping penjelasan mengenai tindakan medis dan alasannya, juga memuat kesanggupan pasien/keluarganya untuk membayar biaya medis tersebut. Tindakan medis dilakukan setelah urusan administrasi keuangan diselesaikan oleh pihak pasien, baik sebagian ataupun seluruhnya.

18 "Dr Ayu Menolong Pasien di Penjara Bebas Kini Beraksi di MK", https://news.detik.com/berita/ 2710494/kisah-dr.-ayu-menolong-pasien-di-penjara-bebas-kini-beraksi-di-mk, diakses tanggal 7 September 2019.

${ }_{19}$ Mukadimah Kode Etik Kedokteran Indonesia yang di Lampirkan pada Keputusan Menteri Kesehatan RI. Nomor: 434/MEN.KES/X/1983 tentang berlakunya Kode Etik Kedokteran Indonesia Bagi para Dokter di Indonesia.

${ }^{20}$ Ketentuan Umum Pasal 1 angka 1 Permenkes No. 290 Tahun 2008

${ }^{21}$ Dr. Zahir Rusyad, Op. Cit., hlm. 5. 


\section{Penutup}

Berdasarkan uraian dan pembahasan atas permasalahan tersebut di atas, maka dapat diambil kesimpulan sebagai berikut: Pertama, banyak hak-hak pasien yang di sampingkan dalam hal perlindungan pasien salah satunya adalah pasien dalam hal transaksi trapeutik atau yang di kenal dengan perjanjanjian medis belum berjalan dengan baik, dalam transaksi trapeutik ada hak dan kewajiban pasien begitupun sebaliknya ada hak dan kewajiban dokter, dokter sebagai penyembuh dan pasien sebagai orang yang membutukan pengobatan untuk di sembuhkan. Kedua, tujuan penyelenggaraan rumah sakit, pada Pasal 3 huruf c Undang-Undang Nomor 44 Tahun 2009 tentang Rumah Sakit adalah memberikan kepastian hukum kepada pasien, masyarakat dan sumber daya manusia. Oleh sebab itu peran rumah sakit sangat penting untuk memantau setiap aktifitas dokter dalam hal menjalankan profesinya, agar tidak terjadi kelalaian yang merugikan pasien tersebut dan juga dokter itu sendiri.

Pelayanan untuk masyarakat di Indonesia secara filosofi berasal dari Pasal 34 ayat (1) UUD 1945 yang menetapkan pelayanan kesehatan sebagai tanggungjawab Negara, dan Pasal $28 \mathrm{H}$ ayat (1) yang menetapkan mengenai hak warga negara untuk mendapatkan pelayanan kesehatan. Oleh sebab itu perlindungan untuk pasien sebagai konsumen rumah sakit harus dlindungi sesuai dengan undang-undang yang berlaku, karena kebutuan akan pelayanan kesehatan masyarakat Indonesia telah menciptakan bisnis rumah sakit dan menjadi bagian yang tak terpisahkan dari pelayanan kesehatan teradap masyarakat.

Sedangkan perlindungan hukum dan pelayanan kesehatan meliputi beberapa aspek: a. aspek administrasi yaitu berkaitan dengan jenis dan mutu pelayanan dasar, yang pada dasarnya adala bisnis dibidang layanan kesehatan yang dilakukan oleh institute, karena jasa yang telah diberikan oleh dokter harus ada timalbalik dari pasien yaitu dengan memberikan upah kepada dokter atau rumah sakit yang menangani. b. aspek pidana, perlindungan warga masyarakat untuk memperoleh layanan kesehatan masyarakat merupakan aspek represif, yaitu ketika teradinya malpraktek oleh dokter rumah sakit. Dalam aspek ini lebih sering menyasar kepada dokter rumah sakit, karena aspek pidana mengedepankan tuntutan kesalahan dokter bukan rumah sakitnya dan akan muncul pertanyaan, apa tanggungawab rmah sakit terhadap dokter yang bekerja di rumah sakit tersebut. c. aspek perdata, aspek perdata ini berkaitan juga dengan perlindungan represif, yaitu perlindungan hukum apabila terjadi kerugian yang di sebabkan oleh kesalahan/kelalaian dokter. Gugatan dilakukan ketika dokter 
rumah sakit melakukan kelaialaian/kesalahan dalam kontrak prestasi atas persetujuan rencara medis.

Ketiga aspek tersebut di atas semuanya mengarah kepada dokter rumah sakit, bukan kepada rumah sakit misalnya kerugian yang di alami pasien yang menjadi beban pertanggungjawaban harusnya rumah sakit diamana dokter tersebut bekerja, tidak semuanya harus dibebani kepada dokter.

Maka dari itu ada sedikit saran yang hendak penulis sampaikan sebagai berikut: Pertama, dalam pelayanan hukum kesehatan di rumah sakit agar tidak merugikan kedua bela pihak terutama pasien yang jadi konsumen rumah sakit sebagai pengguna atau pemakai barang dan jasa di rumah sakit harus di layani dengan baik dan di perhatikan apakah tindakan dokter tersebut sesuai SOP rumah sakit tersebut atau tidak dan juga, jika dokter menyuru perawat lain mengambil ali tindakan dokter maka harus ada dokter lain yang mengawasi agar tidak salah dalam hal memberikan pengobatan. Kedua, untuk penyelesaian kasus jika terjadinya malpraktek di rumah sakit sakit, harus di selesaikan dengan cara kekeluargaan atau penyelesaian sengketa medic di luar pengadilan agar tidak merugikan kedua bela pihak. Ketiga, dalam dunia kesehatan perkara kesehatan selalu di limpahkan ke MKDKI atau Majelis Kehormatan Disiplin Ilmu Kedokteran Indonesia, apakah perbuatan dokter itu malpraktek atau tidak, karena pihak kepolisian tidak langsung mengambil tindakan tersebut

\section{Daftar Pustaka}

\section{Buku}

Ashsofa, Burhan, Metode Penelitian Hukum, Cetakan Keempat, Rhineka Cipta, Jakarta, 2004.

Hasan, Iqbal, Pokok-Pokok Materi Metodologi Penelitian dan Aplikasinya, Ghalia Indonesia, Jakarta, 2002.

Maskawati DKK, Hukum Kesehatan, Cetakan Kesatu, Litera, Yogyakarta, 2018.

Soekanto, Soerjono, Pengantar Penelitian Hukum, UI Press, Jakarta, 1986.

Syamsudin, M., Operasional Penelitian Hukum, PT Raja Grafindo Persada, Jakarta, 2007.

Universitas Islam Indonesia, Buku Pedoman Penulisan Tugas Akhir (tesis) Program Magister Ilmu Hukum, FH UII Press, Yogyakarta, 2010.

Rusyad, Zahir, Hukum Perlindungan Pasien, Setara Press, Malang, 2018.

\section{Hasil Penelitian}

Setiono, "Rule Of Law (Supremacy Hukum)", Tesis, Magister Ilmu Hukum Program Pascasarjana Universitas Sebelas Maret, Surakarta, 2014 


\section{Jurnal}

Rahardjo, Satjipto, "Penyelenggaraan Keadilan Dalam Masyarakat Yang Sedang Berubah", Jurnal Masalah Hukum, 1993.

\section{Internet}

"Dr Ayu Menolong Pasien di Penjara Bebas Kini Beraksi di MK", https:// news.detik.com/berita/2710494/kisah-dr.-ayu-menolong-pasiendi-penjara-bebas-kini-beraksi-di-mk, diakses tanggal 7 September 2019.

“Fakta Kasus Dugaan Malpraktek Rumah Sakit Grha Kedoya Kronologi Hingga Pernyataan Pihak Rumah Sakit", http://wow.tribunnews.com/ 2018/07/11/9-fakta-kasus-dugaan-malpraktik-rs-grha-kedoya-kronologihingga-pernyataan-pihak-rumah-sakit, diakses tanggal 14 Desember 2017.

\section{Peraturan Perundang-undangan}

Undang-Undang Dasar Tahun 1945.

Kitab Undang-Undang Hukum Pidana.

Kitab Undang-Undang Hukum Perdata.

Undang-Undang Nomor 36 Tahun 2014 tentang Tenaga Kesehatan.

Undang-Undang Nomor 44 Tahun 2009 tentang Rumah Sakit.

Undang-Undang Nomor 36 Tahun 2009 tentang Kesehatan.

Undang-Undang Nomor 29 Tahun 2004 tentang Praktek Kedokteran.

Undang-Undang Nomor 39 Tahun 1999 tentang HAM.

Undang-Undang Nomor 8 Tahun 1999 tentang Perlindungan Konsumen. 